University of Wollongong

Research Online

Faculty of Law, Humanities and the Arts Papers (Archive)

$1-1-2017$

Australian law to combat illegal logging in Indonesia: a gossamer chain for transnational enforcement of environmental law

Gregory L. Rose

University of Wollongong, grose@uow.edu.au

Follow this and additional works at: https://ro.uow.edu.au/lhapapers

Part of the Arts and Humanities Commons, and the Law Commons

Research Online is the open access institutional repository for the University of Wollongong. For further information contact the UOW Library: research-pubs@uow.edu.au 


\title{
Australian law to combat illegal logging in Indonesia: a gossamer chain for transnational enforcement of environmental law
}

\author{
Abstract \\ Two countries' combined crime-fighting ability might be greater than the sum of their individual capacities \\ where their capabilities complement each other. This article investigates transnational coordination \\ against environmental crime. Australian utilization of mutual legal assistance and anti-money laundering \\ mechanisms to prosecute offences related to illegal logging in Indonesia are examined as a case study. \\ In theory, interrupting the transfer of proceeds of environmental crime across national borders enhances \\ transnational law enforcement. The case study demonstrates that difficult legal obstacles can obstruct \\ practical cooperation between neighbouring countries combating transnational environmental crime in \\ the timber sector. Therefore, international harmonization of environmental crime laws is needed.

\section{Disciplines} \\ Arts and Humanities | Law

\section{Publication Details} \\ G. Rose, 'Australian law to combat illegal logging in Indonesia: a gossamer chain for transnational \\ enforcement of environmental law' (2017) 26 (2) Review of European, Comparative and International \\ Environmental Law 128-138.
}


Australian Law to Combat to Illegal logging in Indonesia: A Gossamer Chain for Transnational Enforcement of Environmental Law

Gregory Rose*

Two countries; combined crime-fighting ability might be greater than the sum of their individual capacities where their capabilities complement each other. This article investigates transnational coordination against environmental crime. Australian utilization of mutual legal assistance and anti-money laundering mechanisms to prosecute offences related to illegal logging in Indonesia are examined as a case study. In theory, interrupting the transfer of proceeds of environmental crime across national borders enhances transnational law enforcement. The case study demonstrates that difficult legal obstacles can obstruct practical cooperation between neighbouring countries combating transnational environmental crime in the timber sector. Therefore, international harmonization of environmental crime laws is needed.

\section{INTRODUCTION}

The connections between transnational crime and environmental crime are present in illegal logging. This article surveys Australian and Indonesian laws against illegal logging and against dealing in the proceeds of crime, with a view to analysing whether those countries' laws can work together. It commences by placing IndonesianAustralian illegal timber trade within the context of transnational environmental crime and compares the criminalization of illegal logging and of dealing in the proceeds of crime within each jurisdiction. It then undertakes a case study that follows the proceeds from Indonesian illegal logging in Australian law with a view to their confiscation. It focuses on 'dual criminality' and finds that Australian laws can be used to seize proceeds from illegal logging in Indonesia. However, prosecutions for illegal logging and related crimes, such as money laundering, require a commitment of law enforcement resources and concomitant international cooperation. The practical hurdles in securing evidence may be insuperable. Nevertheless, the return on cooperative labours will be greater than the sum of each country's lone actions.

\section{TRANSNATIONAL ENVIRONMENTAL CRIME}

An environmental crime can be defined as an action in breach of a national environmental law where that breach is subject to prosecution and, on conviction, the imposition of criminal penalties. ${ }^{1}$ The term 'transnational environmental crime' simply refers to environmental crime that has elements that cross national borders. ${ }^{2}$

The nature of the cross-border elements can vary widely, from physical acts such as simple poaching and smuggling by a lone operator, to intangible acts such as conspiring

\footnotetext{
* Corresponding author.

Email: grose@uow.edu.au

${ }^{1}$ G. Mueller, 'An Essay on Environmental Criminality', in: S. Edwards, T. Edwards and C. Fields (eds.), Environmental Crime and Criminality (Garland, 1996), 3, at 5-6.

${ }^{2}$ For perspectives on transnational environmental crime, see: L. Elliott and W.H. Schaedla (eds.), Handbook of Transnational Environmental Crime (Edward Elgar, 2016).
} 
in complex layered transactions across multiple jurisdictions by organized criminal syndicates. ${ }^{3}$ The latter might include bribery and corruption to support the domestic commission of the offence, ${ }^{4}$ whilst money laundering disguises the illicit origin of proceeds and facilitates their transboundary movement back to criminals. ${ }^{5}$

For example, 'ramin', a valuable once plentiful species of light hardwood that has been depleted in Indonesia, is subject to a national ban on logging and commercial trade. It is logged illegally in protected areas, such as the Tanjung Puting National Park in Indonesian Borneo. Neighbouring Malaysia is a transit destination for illegally sourced Indonesian ramin to be issued with fraudulent certificates of origin. ${ }^{6}$ After transport to processing centres such as China, India and Vietnam and conversion into timber products, ${ }^{7}$ it is exported via other countries such as Hong Kong, Singapore or Taiwan for marketing to consumers in Europe, North America, China or Japan. ${ }^{8}$ It has been alleged that some of the world's largest flooring companies acquire cheap timber at auction on the 'spot market' indifferent to its illegal origin. ${ }^{9}$ These timber harvesting and transportation structures, and the movement of proceeds back to Indonesia, evidence the complicated transnational networks familiar to organized timber crimes. ${ }^{10}$

Illegal logging stands out as one of the world's most profitable forms of environmental crime. It is estimated that approximately $10 \%$ of global timber is produced illegally. In 2015 , the global timber market was estimated at US $\$ 250$ billion of which US $\$ 25$ billion was attributable to illegal sourcing. ${ }^{11}$ Illicit timber production at such volumes drives down the commodity price and harms the licit industry by over-saturating the timber market. ${ }^{12}$ It can also cause declines in public revenue, biodiversity, soil, water quality,

\footnotetext{
${ }^{3}$ M. Levi, 'Breaking the Economic Power of Organised Crime Groups', in: D. Siegel, H. van de Bunt and D. Zaitch (eds.), Global Organized Crime (Springer, 2003), 117.

${ }^{4}$ Environmental Investigation Agency (EIA) and Telapak Indonesia, 'The Thousand Headed Snake: Forest Crimes, Corruption and Injustice in Indonesia' (2007), at 1; WWF - United Kingdom, 'Fighting Forest Crime and the Illegal Timber Trade' (2004).

${ }^{5}$ B. Setiono, 'Fighting Illegal Logging and Forest related Financial Crime: The Anti-Money Laundering Approach' (Presentation at the Workshop on Transnational Environmental Crime and Illegal Resource Activity in the Asia Pacific, the Australian National University, Canberra, 22-23 March 2007). Specific advocacy for the use of anti-money laundering (AML) regimes to combat illegal logging in Indonesia was led by BamBang Setiono, an economist with the Centre for International Forestry Research (CIFOR) 1ocated in Bogor, Indonesia.

${ }^{6}$ EIA and Telapak Indonesia, 'Timber Trafficking: Illegal Logging in Indonesia, South East Asia and International Consumption of Illegally Sourced Timber' (2001), at 17 and 23-25.

${ }^{7}$ EIA and Telapak Indonesia, 'The Last Frontier: Illegal Logging in Papua and China's Massive Timber Theft' (2005), at 10 and 22; EIA and Telapak Indonesia, 'Vietnam: How the Country Has Become a Hub for the Region's Illegal Timber Trade' (2008).

${ }^{8}$ A. Hoare, 'Tackling Illegal Logging and the Related Trade: What Progress and Where Next?'(Chatham House, 2015), at 25.

${ }^{9}$ Documentation for this timber is rarely provided by auctioneers indifferent to its provenance. EIA and Telapak Indonesia, 'Behind the Veneer: How Indonesia's Last Rainforests Are Being Felled for Flooring' (2006).

${ }^{10}$ G. Bruinsma and W. Barnasco, 'Criminal Groups and Transnational Illegal Markets', 41:1 Crime, Law \& Social Change (2004), 79, at 80.

${ }^{11}$ See A. Hoare, n. 8 above.

${ }^{12}$ D. Brack, K. Gray and G. Hayman, 'Controlling the International Trade in Illegally Logged Timber and Wood Products' (Chatham House, 2002), at 9 and 12.
} 
climate management and the rule of law. ${ }^{13}$ The timber illegally produced in Indonesia in 2013 was estimated to cost the government US\$2 billion in revenue. ${ }^{14}$

Illegal logging is most commonly associated with developing equatorial States, but it occurs in all types of forests throughout South-East Asia, Central Africa, Eastern Europe, Russia, South America and North America. ${ }^{15}$ About $50 \%$ of the world's illegal timber (i.e., 40 million $\mathrm{m}^{3}$ ) in 2013 came from Indonesia. ${ }^{16}$ Half of all illegally produced timber is destined for China, which has become the world's major processing hub for wood products. ${ }^{17}$

\section{INDONESIAN-AUSTRALIAN ILLEGAL TIMBER NEXUS}

By 2004, over one-third of Indonesian forest had been devastated by illegal logging, 43 million from an original 120 million hectares. ${ }^{18}$ Estimates of the percentage of illegal logging are high, $40 \%$ of total timber production as at 2013, down from a peak at over $80 \%$ illegal production in $2000 .{ }^{19}$ The decline reflects a shift away from major logging concessions in natural forests, to plantations for the production of timber (for pulp and paper) and for oil palm. Despite the decline in the percentage of illegal logging, the rate of deforestation overall is increasing due to illegal forest conversion for oil palm and timber plantation, as well as the entry of small-scale producers. ${ }^{20}$

Indonesia is Australia's third most valuable supplier of regulated timber products and, during the period 2009-2013, Indonesian timber product exports to Australia annually averaged US\$394.5 million. ${ }^{21}$ Tracing the legal origin of timber products is difficult, with only an estimated $8 \%$ being raw timber and the rest constituting furniture, paper,

\footnotetext{
${ }^{13}$ EIA, 'Illegal Logging Overview' (2005); A. Hoare, n. 8 above, at viii.

${ }^{14}$ See A. Hoare, n. 8 above, at 7.

${ }^{15}$ WWF, 'Forest Crime: A Disappearing Act with Tragic Consequences' (2008).

${ }^{16}$ See A. Hoare, n. 8 above, at ix.

${ }^{17}$ Ibid., at vii and 8 .

${ }^{18}$ A. Hoare and L. Wellesley, 'Illegal Logging and Related Trade: The Response in Indonesia' (Chatham House, 2014), at 4.

${ }^{19}$ Ibid., at 5, 23; A. Dermawan, K. Obidzinski and S. Amira 'Monitoring Illegal Logging at the National Level: Lessons from Indonesia', in: G. Rose (ed.) Following the Proceeds of Environmental Crime: Fish Forests and Filthy Lucre (Routledge, 2014), 141, at 151; Senaca Creek Associates and Wood Resources International, 'Illegal Logging and Global Wood Markers: The Competitive Impacts on the U.S. Wood Products Industry' (American Forest and Paper Association, 2004), at 65.

${ }^{20}$ See A. Hoare and L. Wellesley, n. 18 above, at 5.

${ }^{21}$ Australian Department of Agriculture and Indonesian Ministry of Forestry 'Country Specific Guideline for Indonesia' (21 October 2014), at 5. The value of Indonesian imports was US\$452 million in 2005 and has trended down slightly over the past decade; see Jaakko Poyry Consulting, Overview of Illegal Logging (JP Management Consulting, 2005), at 12.
} 
plywood and other processed building products. ${ }^{22}$ It has been estimated that $9 \%$ of the total amount of timber and timber products imported to Australia is sourced illegally. ${ }^{23}$

The Australian Government has sought for several years to reduce the importation of illegal timber and related products, and to ensure that all forest products imported into Australia are sustainably sourced. ${ }^{24}$ Some timber importers adopted voluntary standards internal to the industry and $22 \%$ of importers relied on forest certification schemes to verify the legality of timber, such as the Australian Forestry Standard. ${ }^{25}$ Until recently, there was no national industry-wide standard to avoid the importation, use and sale of illegally sourced timber products. ${ }^{26}$ The Australian Parliament adopted a timber legality framework, the Illegal Logging Prohibition Act, to promote trade in legally logged timber in 2012. It imposes obligations on importers and processers to exercise due diligence to manage the risk of handling illegally logged timber. ${ }^{27}$

\section{CRIMINALIZATION OF ILLEGAL LOGGING}

Illegal logging is a term commonly used but not formally defined. It is set out here as the sourcing, transport or conversion of timber in contravention of national laws including sourcing of timber from: areas without permission or in breach of logging permit conditions; internationally or domestically recognized protected zones; protected species; or in excess of authorized limits, as well as the conduct of such activities with permits obtained through corruption or without paying the legally required fees and taxes. $^{28}$

\section{INDONESIA}

There has been a decentralization of power in recent years in many areas of Indonesian governance of natural resources from national to local legislatures. ${ }^{29}$ The national legislature retains superior authority and the following discussion considers the legislative regime at a national level.

Indonesian logging was initially regulated in 1967 under national forestry laws in a piecemeal fashion. Following President Soeharto's 'New Order' regime, the Habibie

${ }^{22}$ An illustration is available in a complaint lodged in 2008 by Kimberly-Clark Australia, a tissue paper manufacturing company, with the Department of Agriculture Fisheries and Forestry in conjunction with the Australian Customs Service, concerning toilet paper marketed under the discount brand-name of one of Australia's leading supermarket chains. It alleged the dumping of toilet paper tissue in the Australian market by Asia Pulp and Paper, a company with Indonesian connections that was accused of using illegal and unsustainable logging practices. C. LaFrenz, 'Anti-dumping Case Heads for Appeal', Australian Financial Review (14 January 2009).

${ }^{23}$ See Jaakko Poyry Consulting, n. 21 above.

${ }^{24}$ Department of Agriculture Fisheries and Forestry, 'Bringing Down the Axe on Illegal Logging' (2007), at 4 .

${ }^{25}$ The Timber Developers Association of Australia, 'A Review of the Current Policies and Practices Employed by Timber and Timber Product Importers to Determine the Legality of Supply' (2006), at 20.

${ }^{26}$ A. Schloenhardt, 'The Illegal Trade of Timber and Timber Products in the Asia-Pacific Region' (Australian Institute of Criminology, January 2008), at 14 and 123.

${ }^{27}$ Illegal Logging Prohibition Act 2012 (Cth) ('Illegal Logging Prohibition Act').

${ }^{28}$ This definition is adapted from that provided by A. Hoare, n. 8 above, at 2.

${ }^{29}$ I. Aju Pradnja Resosudarmo, 'Closer to People and Trees: Will Decentralisation Work for the People and the Forests of Indonesia?', in: J. Ribot and A. Larson (eds.) Democratic Decentralisation through a Natural Resource Lens (Routledge, 2005), 117. 
Government passed a Law on Forestry ${ }^{30}$ to govern the industry comprehensively. ${ }^{31}$ The term 'illegal logging' ('pembalakan liar') is not defined in the Law on Forestry and its meaning must be understood from the specifically proscribed conduct, such as causing forest harm. ${ }^{32}$ The proscribed conduct constitutes serious offences under the Indonesian Penal Code (which divides unlawful conduct between serious and lesser offences), attracting penalties of 5-10 years imprisonment and hefty fines. ${ }^{33}$ Investigations are conducted by forestry officials ${ }^{34}$ and powers to arrest and detain are held by the police ${ }^{35}$ who ultimately decide whether a criminal prosecution should be initiated. ${ }^{36}$ National Police investigation progress and the governance integrity in the Ministry of Forests remain weak. For example, in Riau, Sumatra, investigations into 13 of 14 companies suspected of illegal logging were unexpectedly discontinued in late $2008 .^{37}$

Unfortunately, corruption is endemic at the local level in both the forestry and police services. ${ }^{38}$ In 2005, as part of a policy against corruption, then President Susilo Bambang Yudhoyono instructed prosecutors to prosecute illegal logging in connection with corruption. ${ }^{39}$ A specialized team was established to boost the national effort and the Government enjoyed some success, disclosing that certain criminals engaged in illegal logging had connections with major companies. Indonesia's Corruption Eradication

\footnotetext{
${ }^{30}$ Law No. 41/1999 on Forestry ('Law on Forestry').

${ }^{31}$ In 2004, the Megawati Government added provisions that grandfathered mining inside forest areas under agreements made prior to the Law on Forestry, ibid., until the termination of such agreements (Law No. 19/ 2004 on the Approval of Presidential Decree No. 1/ 2004 on the Amendment of the Law on Forestry).

${ }^{32}$ The Law on Forestry, n. 30 above, defines illegal conduct as activity by a person or corporation that: harms the forest, even though a license to undertake certain kind of activities has been granted by the authorities (Section 50.2); cuts timber inside the forest area within a prohibited distance from lakes, dams, water-sources (wells), rivers, river-tributaries, cliffs or shores (Section 50.3(c)); cuts timber or harvests or collects forest products inside forests without possessing a right or a license from an authoritative official (Section 50.3(e)); takes, buys, sells, takes for exchange, entrusts, stores, or possesses forest products, known or reasonably suspected to have originated from forest areas and to have been collected illegally (Section 50.3 (f)); transports, controls or possesses forest products without a Legal Forest Product Transportation Permit concerning the legality of the forest products (Section 50.3(h)); or brings heavy tools and/or other tools that would reasonably be expected to be used to transport forest products inside a forest area, without approval from an official in authority (Section 50.3(j)).

${ }^{33}$ Most offences are punishable by up to 10 years imprisonment and a fine of 5 billion rupiah (US $\$ \$ 0.5$ million) but the offence of transporting, controlling or possessing illegal forest products has a maximum of 5 years and 10 billion rupiah (US\$ $\$ 1$ million), while bringing equipment for transportation of forest products without authorisation carries up to 5 years and 5 billion rupiah (Law on Forestry, ibid., Section 78).

${ }^{34}$ Forest Department investigators have crime investigation powers in relation to forests, forests areas and forests products. Ibid., Section 77.

${ }^{35}$ The police have powers to conduct search and seizure and to take statements of evidence over any crime; see Law No. 2/2002 on Indonesian National Police.

${ }^{36}$ The police lay a criminal charge at the initial step of conducting an investigation, without obligation to consult with another agency; see Law No. 8/1981 on Indonesian Criminal Procedures.

37 'ICW: Ada Konspirasi Keluarnya SP3 Pembalakan Liar', Kompas (26 December 2008), found at: $<$ http://olahraga.kompas.com/read/2008/12/26/17390235/icw.ada.konspirasi.keluarnya.sp3.pembalakan.li ar>.

${ }^{38}$ Indonesia ranks amongst the most corrupt States in the world, although the situation is improving; e.g. where ' 1 ' ranks as least corrupt, the country was ranked 88th in 2016, 107th in 2014, 142nd in 2007, and 137th in 2005. See: Transparency International, 'Corruption Perception Index', found at: <http://www.transparency.org/policy_research/surveys_indices/cpi/2007>.

${ }^{39}$ Presidential Instruction No. 4/2005 on Eradication of Illegal Logging in Forestry.
} 
Commission has made progress, with at least two successful major corruption prosecutions,${ }^{40}$ but the difficulties of securing evidence of corrupt behaviour remain frustrating. Timber crime reports have fallen, perhaps due to greater criminal sophistication. ${ }^{41}$ The most common convictions are of truck drivers carrying illegal logs. No evidentiary link tends to be found between the drivers and any information held in financial institutions concerning money laundering by the timber barons. ${ }^{42}$

\section{AUSTRALIA}

Australian laws against illegal logging do not parallel those of Indonesia. Australia is a federation where the primary responsibility for forest management and law enforcement lies with sub-national state and territory governments. ${ }^{43}$ They are signatories to the Australian National Forest Policy Statement, which promotes nationally coordinated forest policy, and has goals of developing an 'economically viable and ecologically sustainable forest industry', ${ }^{4}$ including the prevention of illegal logging. The states have concluded Regional Forest Agreements with the Federal Government that provide frameworks for their respective forest conservation efforts. Although the term 'illegal logging' is not used or defined in these instruments, proscriptions of breaches of the relevant legislation define pertinent crimes in each sub-national jurisdiction.

A cursory survey of the legislation indicates that offences related to illegal logging are minor, attracting relatively modest penalties, rather than indictable (i.e., entailing a jail sentence of up to a year or more). For example, in New South Wales, the cutting or removal of any timber from a state forest is an offence attracting a fine or six months imprisonment. ${ }^{45}$ In instances where the illegal logging occurs in a national park in New South Wales, it is prohibited to possess or sell a protected native plant attracting a fine or six months imprisonment. ${ }^{46}$

Constitutional jurisdiction over imports and exports gave the federal government the power to legislate over the Australian trade in illegally harvested timber. ${ }^{47}$ It defines illegally logged as timber that has been 'harvested in contravention of laws in force in the place (whether or not in Australia) where the timber was harvested' ${ }^{48}$ Accordingly, the Illegal Logging Prohibition Act 2012 makes it an offence to intentionally, knowingly or recklessly import or process illegally logged timber or timber products. This of-

\footnotetext{
${ }^{40}$ A.C. Sinaga and S. Mardia, 'An Integrated Law Enforcement Approach: Targeting the Proceeds of Forest Crime in Indonesia’, in: G. Rose, n. 19 above, 159, at 162.

${ }^{41}$ See A. Hoare and L. Wellesley, n. 18 above, citing C. Nellemann, Green Carbon, Black Trade (INTERPOL Environmental Crime Programme, 2012).

${ }^{42}$ B. Setiono and Y. Husein, 'Fighting Forest Crime and Promoting Prudent Banking for Sustainable Forest Management' (CIFOR, 2005), at 5. This is so, despite the offering of incentives to officers in the field, which is itself an uncommon practice in Indonesia.

${ }^{43}$ Department of Agriculture, Fisheries and Forestry, 'National Forest Policy Statement' (1992), at 1.

${ }^{44}$ Department of Agriculture, Fisheries and Forestry, 'Australia's State of the Forests Report' (2003), at 309.

${ }^{45}$ Forestry Act 1916 (NSW), Section 27. The fine is 50 penalty units (AU\$5,500).

${ }^{46}$ National Parks and Wildlife Act 1974 (NSW), Sections 117-118. The fine is 100 penalty units (AU\$11,000).

${ }^{47}$ Australian Constitution, Section 51(i).

${ }^{48}$ Illegal Logging Prohibition Act 2012, Section 7.
} 
fence is indictable, and entails up to five years imprisonment. ${ }^{49}$ However, it does not criminalize the illegal logging itself but, rather, dealing in the proceeds of the crime.

\section{ILLEGAL TIMBER HANDLING AND LAUNDERING CRIMES}

Money laundering is essentially the hiding of goods or profits obtained by criminal means from the attention of law enforcement agencies and other criminals. ${ }^{50}$ It also involves dealing in property which is the proceeds of crime. ${ }^{51} \mathrm{~A}$ three-part definition of money laundering derived from the Convention on Transnational Organised Crime is: (i) any act which is performed directly, or through a third party intermediary; (ii) which deals with funds, property or recognizable legal rights of any kind; (iii) when such act is designed to prevent the discovery of the origin of the property. ${ }^{52}$ An intergovernmental Financial Action Task Force (FATF) was established by the Group of 7 in 1989 at the Organisation for Economic Co-operation and Development (OECD). It issued recommendations in 1990 to combat money laundering. The 40 recommendations are implemented to varying degrees in 182 economic jurisdictions. ${ }^{53}$

In the context of money laundering, the original crime is called a predicate offence. Although the operation of money laundering offences was traditionally confined to the proceeds of well-recognized crimes such as drug trafficking, the range of predicate offences is broadening in accordance with FATF recommendations to include environmental crimes. ${ }^{54}$ It would be difficult to continue to profit from the massive illegal exploitation of forestry resources without concealing the criminal origin of timber proceeds by utilising money laundering techniques. Illegal logging is, thus, inextricably linked to money laundering and anti-money laundering (AML) regimes offer a way to combat it. ${ }^{55}$

\footnotetext{
${ }^{49}$ Ibid., Sections 8-9 and 15.

${ }^{50} \mathrm{~J}$. Broome, Anti-Money Laundering - international practice and policies (Sweet \& Maxwell Asia, 2005), at 3. There are three typical stages to the process of hiding the origin of the proceeds of crime: (i) placement: proceeds are placed into the legitimate market and financial system; (ii) layering: proceeds are transferred between persons, accounts and jurisdictions, in order to change form and currencies and disguise its original origin; and (iii) integration: layered proceeds are integrated into legal activities. Ibid., at 128.

${ }^{51}$ National AML regimes have progressively been implemented worldwide since the Convention against Illicit Traffic in Narcotic Drugs and Psychotropic Substances (Vienna, 20 December 1988; in force 1 November 1990), Article 3.1(b)-(c). called for their implementation. The Convention on Transnational Organized Crime (New York, 15 November 2000; in force 29 September 2003), Articles 6-7, requires that its parties implement AML regimes (Articles 6-7), as does the 2003 Convention against Corruption (New York, 31 October 2003; in force 14 December 2005), Article 14, and other international agreements. See: United Nations Office of Drugs and Crime (UNODC), 'An Overview of the United Nations Conventions and Other International Standards Concerning AML and Countering the Financing of Terrorism' (UNODC, 2007), at 43-48.

${ }^{52}$ Convention on Transnational Organized Crime, n. 51 above, Article 14.

${ }^{53}$ FATF, 'The Forty Recommendations of the Financial Action Task Force on Money Laundering' (1990), found at: <http://www.fatfgafi.org/media/fatf/documents/recommendations/pdfs/FATF\%20Recommendations\%201990.pdf>.

${ }^{54}$ Ibid., Recommendation 1 states that countries should criminalize money laundering in relation to all serious offences, or a threshold of offence categories or penalties, or listed offences. Environmental crime is listed as a category of offence in the glossary.

${ }^{55}$ See B. Setiono and Y. Husein, n. 42 above, at 9 and 30.
} 


\section{INDONESIA}

In 2002, the Indonesian Government introduced laws to criminalize money laundering. ${ }^{56}$ The offences that could trigger prosecution for money laundering were specified. ${ }^{57}$ The new laws were considered by the FATF as being an inadequate implementation of the relevant items in its ' 40 recommendations' to combat money laundering and it threatened to blacklist financial transactions with Indonesian financial institutions unless further and more comprehensive implementation was achieved. ${ }^{58}$ Consequently, an expanded range of offences was introduced through amendments in $2003 .{ }^{59}$ The predicate offences now include forestry, environmental and maritime offences and any offence subject to four years imprisonment. ${ }^{60}$

An expanded range of AML duties was identified, which obliged financial institutions to be more prudent in ensuring compliance with the new system and to conduct a higher level of due diligence on their transactions. ${ }^{61}$ Large cash transactions and suspicious transactions are to be reported to the Indonesia Transactions Report and Analysis Centre (PPATK). ${ }^{62}$ Penalties for money laundering were also increased. They are 5-15 years imprisonment and a fine of 100 million-5 billion rupiah (US\$10,000 to $\$ 1.5$ million). ${ }^{63}$ Instead of imprisonment, corporate contraventions may result in penalties such as dissolution, liquidation and the revocation of business licences. ${ }^{64}$ In addition to these sanctions, the instruments used to commit the crimes and the criminal proceeds are both subject to forfeiture ${ }^{65}$ and there is provision for confiscation of the proceeds of crime upon conviction for a predicate offence. A civil procedure to seize property embezzled from the State is available to government agencies ${ }^{66}$ and introduction of a non-conviction dependent law on civil forfeiture is currently under consideration by the Indonesian legislature. $^{67}$

\footnotetext{
${ }^{56}$ Law No. 15/2002 on the Crime of Money Laundering; and Law No. 25/2003 Amending Law No. 15/2002 ('Law on the Crime of Money Laundering'). Section 1 defines money laundering as 'an act of placing, transferring, disbursing, spending, donating, contributing, entrusting, taking out of the country, exchanging or other such act related to assets known or reasonably suspected by a person to constitute proceeds of crime, for the purpose of concealing or disguising the origins of assets as if such assets were legitimate'.

${ }^{57}$ Ibid., Section 2. The predicate offences were: corruption, bribery, smuggling of goods, smuggling of workers, smuggling of immigrants, banking offences, trafficking in narcotics, psychotropic substances, people and illegal arms, kidnapping, terrorism, theft, embezzlement, fraud and prostitution.

${ }_{58}$ B. Setiono and C. Barr, 'Using Anti-Money Laundering Laws to Fight Forestry Crime in Indonesia' (CIFOR, 2003).

${ }^{59}$ See generally Law on the Crime of Money Laundering, n. 56 above.

${ }^{60}$ Ibid., Section 2. Forestry offences are referenced at Section 2(v).

${ }^{61}$ Ibid., Sections 13-17A. For example, financial service providers must report suspicious transactions within 3 days of their identification.

${ }^{62}$ Ibid., Section 17 (c).

${ }^{63}$ Ibid., Sections 3, 6 and 7.

${ }^{64}$ Ibid., Sections 4-5.

${ }^{65}$ Ibid., Section 34.

${ }^{66}$ Law No. 31/1999 on Eradication of the Crime of Corruption, Section 32.

${ }^{67}$ B. Laksmana 'Recovery of Proceeds of Corruption: The Indonesian AGO's Point of View' (United Nations Asia and Far East Institute, 2015). A. Wibawa et al., 'The Recovery of the Assets of the Criminal Acts of Corruption as the Country's Financial Rescue Efforts', 3:2 Journal of Humanity (2015), 108.
} 
The PPATK is the key Indonesian authority responsible for AML activity. ${ }^{68}$ In particular, it has the authority to identify, investigate, and request the confiscation of the proceeds of crime. However, as is usual for financial intelligence units, the PPATK does not have prosecutorial powers. The Indonesian National Police have sole authority to prepare a dossier and, if the financial crimes investigation unit is satisfied that conduct should be prosecuted, the police refer the matter to the Public Prosecutor's Office or the Attorney-General who may authorise prosecution. ${ }^{69}$ The inability of PPATK to bring prosecutions in its own right can frustrate its AML activities as the Indonesian National Police do not have similar skills to PPATK analysts and remain subject to corruption.

An Indonesian Timber Legality Assurance System (TLAS) ${ }^{70}$ was introduced in 2012. It serves to suppress laundering of illegally harvested logs by requiring that exporters of Indonesian timber products obtain a Timber Legality Certificate ('SVLK') for harvested timber and a V-Legal verification document for each shipment. In 2013, Indonesia became the first Asian country to sign a Voluntary Partnership Agreement under the European Union (EU) Timber Regulation concerning the legality of harvested timber exported to the European Union common market. ${ }^{71}$ It then was the first country in the world, on 15 November 2016, to be authorized to issue licences under this EU Regulation. The EU Forest Law Enforcement Governance and Trade (FLEGT) licences are issued subject to a Timber Legality Certificate under the TLAS. Importers into the EU of timber products covered by a FLEGT licence are exempted from undertaking their own independent due diligence checks on the legality of the source of timber. The licensing system is in its early days and is overseen by an EU-Indonesia Joint Implementation Committee.

\section{AUSTRALIA}

Criminal proceeds in Australia were estimated in 2004 to be worth AU\$4.5 billion a year. ${ }^{72}$ The Australian Criminal Code proscribes money laundering ${ }^{73}$ and the AntiMoney Laundering and Counter-Terrorism Financing Act (AML-CTF Act), ${ }^{74}$ Financial Transactions Reports $\mathrm{Act}^{75}$ (AUSTRAC Act) and the Proceeds of Crime Act ${ }^{76}$ also play key roles in an administrative regime to identify transactions involving the proceeds of crime (or financing of terrorism) and to institute a mechanism for the confiscation of any such proceeds.

\footnotetext{
${ }^{68}$ It was established under the Law on the Crime of Money Laundering, n. 56 above Sections 18-29B.

${ }^{69}$ See B. Setiono and Y. Husein, n. 42 above, at 16-17.

${ }^{70}$ Sistem Verifikasi Legalitas Kayu (SVLK), pursuant to Director-General of Forest Production Development Regulation No. P. B/VI-BPPHH/2012.

${ }_{71}$ Chatham House, Illegal Logging Portal - Indonesia (2017), found at: <http://www.illegallogging.info/regions/indonesia>. Regulation 995/2010/EU of 20 October 2010 Laying Down the Obligations of Operators who Place Timber and Timber Products on the Market, [2010] OJ L295/23.

${ }^{72}$ This figure is based on estimates of the proceeds of crime generated by a diverse array of offences. Estimates range between AU\$2.8 and AU\$6.3 billion, with the most likely figure being a mean of AU\$4.5 billion. See J. Walker, 'The Extent of Money Laundering in and Through Australia in 2004' (2005).

${ }^{73}$ Criminal Code Act 1995 (Cth) ('Criminal Code').

${ }^{74}$ Anti-Money Laundering and Counter-Terrorism Financing Act 2006 (Cth) ('AML-CTF Act').

${ }^{75}$ Financial Transactions Reports Act 1988 (Cth).

${ }^{76}$ Proceeds of Crime Act 2002 (Cth).
} 
The Illegal Logging Prohibition Act 2012 makes it an indictable offence to import illegally logged timber, ${ }^{77}$ to import it in regulated timber products, ${ }^{78}$ or to process illegally logged raw logs. ${ }^{79}$ Thus, it criminalizes certain forms of handling (importation or processing) of the proceeds of a specified crime (illegal logging). ${ }^{80}$ The criminal intent is premised on a culprit's failure to meet the statutory duty of due diligence. The Act's regulations specify due diligence requirements as: (i) information gathering; ${ }^{81}$ (ii) checking the reliability of the information by using a timber legality framework or country-specific guideline; (iii) risk assessment by considering whether other information might indicate illegality; and, if so, then (iv) risk mitigation. ${ }^{82}$ The use of a recognized timber legality assurance framework refers to a standard in international use such as that of the EU, ${ }^{83}$ whereas compliance with a country-specific guideline refers to a recognized national system such as the Indonesian TLAS. ${ }^{84}$ If no timber legality framework or national guideline is in place, it becomes necessary to conduct an independent risk assessment (step iii above), taking into account the prevalence of illegal logging in the harvesting area, illegal harvesting of the specific species, and the presence of armed conflict as risk factors, as well as the complexity of the product and any other available information. ${ }^{85}$ The risk mitigation process (which requires making a written record of the process of consideration) must be proportionate to the identified risk and may include a decision not to import a timber product. ${ }^{86} \mathrm{~A}$ fine applies for a failure to undertake any step of the due diligence requirements.

The Criminal Code (Division 400) criminalizes general dealings with, including importing, the proceeds of crime. ${ }^{87}$ Property is defined in broad enough terms to include timber. ${ }^{88}$ Conduct is criminalized when a person deals in money or property that is the proceeds of crime. ${ }^{89}$ The dealings are criminalized whether a person acted with deliberate intent, recklessness or negligence in relation to the fact that the property is proceeds of crime, although the applicable penalties diminish as the person's conscious deliberation attenuates. ${ }^{90}$ In addition, the possession of property reasonably suspected of being proceeds of crime is criminalized. ${ }^{91}$ It is not necessary to prove that the particular predicate

\footnotetext{
${ }^{77}$ Illegal Logging Prohibition Act, n. 48 above, Section 8

${ }^{78}$ Ibid., at Section 9, prescribed in the Illegal Logging Prohibition Regulation 2012 (Cth).

${ }^{79}$ Illegal Logging Prohibition Act, n. 48 above, Section 15.

${ }^{80}$ A similar approach was adopted in a 2008 amendment to the Lacey Act, which criminalized the importation of illegally harvested timber. US Lacey Act (Food, Conservation and Energy Act of 2008, Pub. L. No. 110-234, § 8204, 122 Stat. 923 (codified at 16 USC $\S \$ 3371-3378$ ).

${ }^{81}$ Illegal Logging Prohibition Regulation, n. 78 above, Section 10.

${ }^{82}$ Illegal Logging Prohibition Act, n. 48 above, Section 18

${ }^{83}$ Illegal Logging Prohibition Regulation, n. 78 above, Section 11. The Schedule to the Regulation lists the legality frameworks of the EU FLEGT, Forest Stewardship Council the Programme for the Endorsement of Forest Certification.

${ }^{84}$ Ibid., Section 12 . The Schedule to the Regulation lists the other country guidelines of Canada, Finland, Indonesia, New Zealand and the Solomon Islands.

${ }^{85}$ Ibid., Section 13.

${ }^{86}$ Ibid., Section 14.

${ }^{87}$ Criminal Code, n. 73 above, Schedule 1, Section 400.2.

${ }^{88}$ Property is defined as including real and personal property, whether tangible or intangible, whether situated inside of outside of Australia, and includes any kind of interest in the abovementioned property. Ibid., Section 400.1.

${ }^{89}$ Ibid., Section 400.3-400.8.

${ }^{90}$ Penalties also diminish in proportion to the worth of the proceeds. Ibid.

${ }^{91}$ Ibid., Section 400.9.
} 
offence was committed or that a particular person committed the offence, but merely the fact that the property dealt with was proceeds of crime. ${ }^{92}$ That threshold fact would need to be proved to the common law criminal standard, i.e. beyond a reasonable doubt. The geographical scope of application of Division 400 includes dealings which occur, in whole or in part, in Australia or which are conducted by Australian residents or citizens. $^{93}$

The federal Proceeds of Crime Act provides for the confiscation of the proceeds of crime. The two forms of confiscation proceedings most relevant to dealing with illegally logged timber would be first, proceeding against assets following a conviction, and second, against suspect assets without conviction. ${ }^{94}$ The first is a criminal procedure that produces forfeiture upon conviction of the predicate offence. This confiscation procedure is not a criminal penalty and is therefore different to prosecution for the predicate offence itself under the Criminal Code. The second is a civil procedure, applicable when there has been no conviction for the predicate crime but when dealing in the proceeds of crime is reasonably suspected. ${ }^{95}$

Part V of the AUSTRAC Act established the Australian Transaction Reports Analysis Centre (AUSTRAC) which is the Australian financial intelligence unit. It is the authority responsible for the performance of functions prescribed by the AML-CTF Act. ${ }^{96}$ AUSTRAC oversees financial reporting requirements by collecting and analysing financial transactions. ${ }^{97} \mathrm{~A}$ wide range of Australian institutions are covered by the AMLCTF Act (including casinos, bullion and gem dealers, law practices, etc.), ${ }^{98}$ which requires them to properly identify their customers ${ }^{99}$ and to report suspicious transactions to AUSTRAC. ${ }^{100}$ AUSTRAC provides its accumulated financial intelligence and information to other authorities such as the Australian Taxation Office, the Australian Federal Police and the Australian Crime Commission. ${ }^{101}$ It, like the PPATK, does not conduct prosecutions itself.

\section{FOLLOWING PROCEEDS FROM ILLEGAL INDONESIAN LOGGING IN AUSTRALIA: A TRANSNATIONAL ENVIRONMENTAL CRIME CASE STUDY}

An AML regime 'follows the money' or other proceeds of crime back to the illegal source. In relation to the proceeds of illegal logging, it starts by identifying a business profile with 'suspicious wealth' and then links the wealth back to the forestry sector and

\footnotetext{
92 Ibid., Section 400.13.

${ }^{93}$ Ibid., Section 400.15. In 2006, Division 400 was amended to include dealing in proceeds of a 'foreign indictable offence': Anti-Money Laundering and Counter-Terrorism Financing (Transitional Provisions and Consequential Amendments) Act 2006 (Cth).

${ }^{94}$ S. Grono, 'Civil Forfeiture: The Australian Experience', in: S. Young (ed.), Civil Forfeiture of Criminal Property: Legal Measures for Targeting the Proceeds of Crime (Edward Elgar, 2009), 125, at 128.

${ }^{95}$ Proceeds of Crime Act 2002 (Cth), Sections 5(a)-(b).

${ }^{96}$ AML-CTF Act, n. 74 above, Section 209.

${ }^{97}$ Ibid., Section 212.

${ }^{98}$ Ibid., Section 6.

${ }^{99}$ Ibid., Part 2.

${ }^{100}$ Ibid., Section 41.

${ }^{101}$ Ibid., Part 11.
} 
to the illegal logging. It has been suggested that Indonesian financial service providers should suspect logging transactions to be high risk. ${ }^{102}$ The PPATK has sought to distinguish normal patterns of forestry transactions from those that are unusual and suspicious. $^{103}$

While the centralized Indonesian AML regime might avoid the obstacles posed by large-scale regional and local corruption within the fragmented forestry regulation system, hopes for successful investigations are based on the premise that there continues to be no obstructing corruption in the centralized financial regulatory system. ${ }^{104}$ The integrity of the current AML regime is supported by intense anti-corruption efforts. ${ }^{105}$ Yet, bribery remains pervasive among forestry officers, police and customs officials, politicians, court officials and judges. ${ }^{106}$ The difficulties were exemplified in the acquittal of a rich and powerful ex-police commissioner on charges of money laundering and corruption ${ }^{107}$ and the release of a high-profile timber baron wanted for money laundering. ${ }^{108}$ Therefore, the PPATK financial intelligence relating to transnational timber crime might be more strategically used in conjunction with foreign AML regimes for prosecutions outside Indonesia. ${ }^{109}$

Australia imports AU $\$ 4.4$ billion Australian of timber and wood products (excluding furniture) annually, of which it is estimated that up to AU\$400 million come from illegally harvested sources. ${ }^{110}$ Although the Commonwealth AML regime has been applied to trafficking in drugs and other contraband, it has not yet been applied to illegal logging.

The Australian capacity to identify, investigate, gather intelligence, prosecute and confiscate the proceeds of crime in relation to transnational organized criminal activities is relatively strong. ${ }^{111}$ The agencies under the Attorney-General, including the Australian Criminal Intelligence Commission, the Australian Federal Police and AUSTRAC, as well as the Department of Agriculture, might combat illegal logging in Indonesia through the focused enforcement of Australian illegal timber and AML laws. AUS-

\footnotetext{
${ }^{102}$ See B. Setiono and Y. Husein, n. 42 above, at 15. The Central Bank of Indonesia (BI) does not identify high-risk customers, transactions or countries in its regulations. See, e.g., BI Circular Letter 5/32/2003 on risk-based customer due diligence is general in nature and does not specify logging transactions as high risk, cited in ibid., at 16.

${ }^{103}$ Ibid.

${ }^{104}$ Ibid., at 14 .

105 Ibid., at 19.

${ }^{106}$ Ibid., at 9.

${ }^{107}$ EIA and Telapak Indonesia, n. 4 above, at 9.

${ }^{108}$ M. Forbes 'Outrage as Timber Baron Walks Free', Sydney Morning Herald (7 November 2007). Upon acquittal for illegal logging, $\mathrm{Mr}$ Adelin Lis was released and became a fugitive from police seeking to prosecute him for money laundering. Police complaints that their investigations had been frustrated by the release resulted in the removal of the deputy in the North Sumatra Provincial Prosecutor's Office and other subordinates, as well as examination of the affair by the internal affairs unit of the AttorneyGeneral's Office in Jakarta and the Judicial Commission.

${ }^{109}$ See B. Setiono, n. 5 above, at 35.

${ }^{110}$ Department of Agriculture and Water Resources, 'Illegal Logging' (30 May 2016), found at: <http://www.agriculture.gov.au/forestry/policies/illegal-logging>.

${ }^{111}$ Australian Institute of Criminology, 'The Worldwide Fight against Transnational Organised Crime: Australia' (2004), at 24; Australian Crime Commission, Organised Crime in Australia: Report on Organised Crime (2008), at 11.
} 
TRAC, in cooperation with PPATK, could track dealings that originate with Indonesian illegal logging and end in Australian importation of the illegally harvested timber. It could also track the proceeds of sales which are made in Australia and that return as cash to Indonesia. AUSTRAC might also consider issuing guidelines for dealers in timber transactions, specifying high standards of due diligence in relation to the detection of illegal logging.

\section{ILLEGAL TIMBER SCENARIO}

The following section brings together the threads of discussion concerning Australian and Indonesian laws by presenting a case to test the potential use of prosecution and confiscation actions in Australia to combat dealings in products from illegal harvesting in Indonesia. In our hypothetical scenario, an Australian owned and operated company, called Hardware Wholesaler, imports timber flooring and fittings from Indonesia. The Australian company's primary source is P.T. Graha Buana, a housing materials company in Indonesia owned and operated by a family in Medan, Sumatra. The company harvests its own raw timber for processing and is known for its illegal logging practices in its operations in both Sumatra and West Papua. It holds licences to export timber products to Australia generated from both the Sumatran and Papuan logging operations.

The Australian division of an environmental advocacy group, called Forest Defence, lobbies publicly against the marketing of P.T. Graha Buana wood products in Australia, collaborating with an Indonesian environment group to gather information concerning the illegal logging and its downstream products. They obtain DNA evidence that the shipment of flooring currently being sold by Hardware Wholesaler is from the species merbau, harvested in West Papua and for which P.T. Graha Buana does not hold a valid logging licence. The information is presented to the Australian Attorney-General together with a call for the prosecution of Hardware Wholesaler for dealing in the proceeds of crime, which are the merbau timber flooring and fittings imported from P.T. Graha Buana, including money from their sale, and the confiscation of those proceeds.

\section{AUSTRALIAN ILLEGAL LOGGING PROHIBITION ACT}

Under the Illegal Logging Prohibition Act 2012, an offence may be committed by importing the timber from P.T. Graha Buana, without the need to prove that the actual timber in the shipment was illegally logged. It is sufficient to prove that it was imported in breach of the due diligence standard owed under Australian law by Hardware Wholesaler. To prove due diligence compliance, the defendant would need to demonstrate either that it made an independent risk assessment and took proportionate mitigation action, or that its shipments conform to requirements of the Indonesian TLAS as demonstrated by a V-Legal document, or that it conforms to an approved international legality framework, as demonstrated by a Timber Legality Certificate. ${ }^{112}$

In relation to a timber legality framework, Hardware Wholesaler would need a certificate issued to the harvester that provides evidence of its compliance with the legality framework. In relation to a country guideline, Hardware Wholesaler would need an In-

\footnotetext{
${ }^{112}$ See n. 83 above.
} 
donesian Timber Legality Certificate. ${ }^{113}$ If it has neither that nor an EU or other equivalent international certificate, then, in light of lobbying by Forest Defence, the risk assessment would have to take into account allegations and information against P.T. Graha Buana, including factors such as the species of timber, place of harvesting, legal rights to harvest and payment for harvesting rights, in order to determine whether it was illegally harvested. Hardware Wholesaler would then have to take proportionate mitigation action. If there is a likelihood of offending against the importation prohibition, the logical action would be not to import.

Breaches of the Illegal Logging Prohibition Act 2012 can lead to both criminal and civil penalties. Criminal penalties of up to five years gaol apply for the intentional, knowing or reckless importation or processing of illegally logged timber or timber products. ${ }^{114}$ Civil penalties in the form of fines (of up to AU\$18,000) apply for breaches of any step of the due diligence requirements. ${ }^{115}$

\section{MUTUAL LEGAL ASSISTANCE}

An Australian investigation concerning alleged money laundering and dealing in the proceeds by Hardware Wholesaler in Australia from illegally harvested timber imported from Indonesia could also be pursued as a separate legal action. The acquisition by Australian investigators of information as to the location of logging sites, conditions of licences, confirmation of DNA data, evaluations of value, shipping operations of P.T. Graha Buana, etc., need the assistance of Indonesian police. To secure international assistance in criminal investigations and prosecutions, national law enforcement authorities must build mutual cooperation relationships with agencies in other countries.

Australia and Indonesia have established a working relationship in law enforcement cooperation only relatively recently. The 1995 Treaty between Australia and the Republic of Indonesia on Mutual Assistance in Criminal Matters entered into force in 1999. ${ }^{116}$ There has not yet been any mutual assistance in matters of environmental crime. Concerning money laundering, the mutual assistance treaty undertakings cover confiscation and forfeiture. Each country may request urgent 'freezing' action by the other to prevent any dealing in, transfer or disposal of suspected proceeds of crime, pending a final determination in respect of those proceeds by a court of the requesting country. ${ }^{117}$ A premise of mutual legal assistance is that the crimes of concern for cooperation be equivalent in each jurisdiction, having the quality of 'dual criminality'. As the laws criminalizing money laundering and the procedures for the confiscation of the proceeds of crime are similar in each jurisdiction, mutual assistance in relation to them should not be problematic. For example, Indonesia has previously requested and been granted assistance in

\footnotetext{
${ }^{113}$ Illegal Logging Prohibition Regulation, n. 78 above, Section 11.

${ }^{114}$ Illegal Logging Prohibition Act, n. 48 above, Sections 8-9.

115 Ibid., Division 5. The due diligence requirements under the Regulation came into effect on 30 November 2014, but with a soft start compliance period until 30 May 2016 that has since been extended. Department of Agriculture and Water Resources, Illegal Logging Compliance Advice Notice 1/2016 (31 May 2016).

${ }^{116}$ Treaty between Australia and the Republic of Indonesia on Mutual Assistance in Criminal Matters (Jakarta, 27 October 1995; in force 17 July 1999).

${ }^{117}$ Ibid., Article 18.
} 
relation to retrieving the proceeds of a major corruption case. ${ }^{118}$ Although legal cooperation has not yet been undertaken in the area of money laundering related to environmental crimes, such as illegal logging, the framework is there to be utilized.

\section{DUAL CRIMINALITY IN PREDICATE OFFENCES}

Under Australian law, not all crimes qualify as predicate offences for AML prosecutions. The Commonwealth Criminal Code identifies only indictable offences, or more serious offences, as predicate offences. ${ }^{119}$ As mentioned above, in cases where that original predicate offence was not committed in Australia, an AML prosecution can still take place. It is not necessary under the Australian law to prove the actual commission by convicted persons of the particular instances of predicate offences. Instead, the predicate offences would need merely to be demonstrated as having occurred. However, the foreign predicate offence needs to be equivalent to an Australian predicate offence. ${ }^{120}$

The definition of a foreign indictable offence requires that there be dual criminality, i.e. that there be an equivalent to the foreign crime in Australia. The essential question then is whether illegal logging in Indonesia is conduct that would, had it occurred in Australia, be an indictable offence under Australian law? Unfortunately, forestry offences in Australia are not indictable. However, other real avenues exist to circumvent this shortfall in dual criminality.

First, as an alternative to the use of correlated forestry offences, the taking of logs might be characterized as a theft of government property. The 'theft of land or things forming part of land' belonging to the Commonwealth ${ }^{121}$ is an indictable offence under Australian law. ${ }^{122}$ This has its correlate in Indonesian law, where illegal logging on Indonesian Government lands is treated as theft from the Indonesian Government. ${ }^{123}$ Major theft of government resources is treated in Indonesian law as corruption. ${ }^{124}$ Second, the link between corruption and illegal logging in Indonesia suggests bribery as a correlating predicate offence under Australian law. Under the Commonwealth Criminal Code there is

\footnotetext{
${ }^{118}$ In the case of Hendra Rahardja, an Indonesian banker who died of cancer while a fugitive from Indonesian authorities in Australia, the Australian Government was successful in repatriating around AU \$ \$650,000 to the Indonesian Central Bank (although out of millions of dollars embezzled). World Bank and UNODC, Stolen Asset Recovery Initiative, Case Studies Database', found at: $<$ http://star.worldbank.org/corruption-cases/node/18507>.

${ }^{119}$ Criminal Code, n. 73 above, Section 400.2(1)(b).

${ }^{120}$ Ibid., Section 400.1(1). It is necessary to establish that the foreign crime was a 'foreign indictable offence', defined as: 'an offence against a law of a foreign country constituted by conduct that, if it had occurred in Australia, would have constituted an offence against: (a) a law of the Commonwealth; or (b) a law of a State or Territory connected with the offence; that may be dealt with as an indictable offence ...'. ${ }^{121}$ Ibid., Section 131.1.

122 Ibid., Section 131.4.

${ }^{123}$ Typically, prosecutions for theft of forest assets by individuals living in or near forests who unlawfully cut, transport or sell logs take place under the ordinary theft provisions of the Indonesian Penal Code. Law No. 31/1999 on Eradication of Corruption (as amended by Law No. 20/2001) was intended to apply to major actors in organised crime.

${ }^{124}$ Ibid., Section 2.1 (as amended) broadly criminalizes the obtaining of benefits by public officials, private persons or corporations, through unlawful conduct that may cause economic harm to Indonesia: 'Any person who unlawfully enriches themself, others or a corporation, thereby potentially causing financial or economical damage to the State, shall serve a long life sentence, or $4-20$ years and fine of 200 million - 1 billion rupiah' (US\$20,000-100,000).
} 
dual criminality, as it is also an indictable offence to give bribes or "corrupting benefits ${ }^{125}$ to a Commonwealth public official. ${ }^{126}$ Third, as both Australian and Indonesia are obliged to outlaw participation in transnational organized crime groups, ${ }^{127}$ and as much of the illegal logging in Indonesia is transnational and organized, proscriptions on participation in transnational organized crime groups might offer yet another basis for establishing dual predicate offences in Australia and Indonesia. However, significant differences in the approach of each country to implementing the obligation to criminalize participation in transnational organized crime negate their equivalence. ${ }^{128}$ Fourth, predicate crimes such as breaches of tax or import/export tariff laws might be applicable depending on the circumstances related to the illegal logging.

Finally, in cases where imported timber itself is of an endangered species, the Commonwealth Environmental Protection Biodiversity Conservation Act proscribes the importation of species listed in circumstances other than those allowed under the Convention on International Trade in Endangered Species of Flora and Fauna (CITES). ${ }^{129}$ Under CITES, international trade in some specified Indonesian timber species has been restricted ${ }^{130}$ and it is therefore an offence to import those timber species for commercial purposes or without an appropriate permit. ${ }^{131}$ This offence carries a penalty of up to 10 years imprisonment or AU $\$ 110,000$. The limitation in relying on predicate offences related to CITES is that they apply only to species listed as 'endangered'. Ramin is listed on Appendix 3 of CITES, thereby prohibiting its commercial trade, ${ }^{132}$ but merbau, the species used in our hypothetical scenario, is not currently listed. ${ }^{133}$

There is a valid argument that practical obstacles to using AML techniques against foreign illegal logging render successful criminal prosecutions unlikely. The complexity of establishing dual criminality in predicate offences for timber crimes forms exemplifies

\footnotetext{
${ }^{125}$ This is similar to a bribe but involves a lesser degree of intention; see Criminal Code, n. 73 above, Section 142.1 .

${ }^{126}$ A bribe is defined as giving, promising to give, offering to give or the provision of, any benefit (material or otherwise) not legitimately due to the public official with the intention of influencing that public official in the exercise of their official duties. Ibid., Division 141.

${ }^{127}$ Both countries have ratified the Convention on Transnational Organised Crime, which sets out that obligation in Article 5.1.

${ }^{128}$ In Australia, for instance, there is no common national approach to the proscription of participation in a criminal group but merely the common law crime of conspiracy, which is supplemented by disparate sub-national generic offences, such as that of consorting with criminals, and targeted approaches that outlaw some gangs (for outlaw gangs, see e.g.: Crimes Act 1900 (NSW), Section 93IK; Serious and Organised Crime (Control) Act 2008 (SA); and a few Commonwealth offences specific to high-profile crime sectors (e.g., people smuggling). These observations are drawn from the Commonwealth Parliament Joint Committee on the Australian Crime Commission, 'Inquiry into the Legislative Arrangements to Outlaw Serious and Organised Crime Group's (2009).

${ }^{129}$ Environmental Protection Biodiversity Conservation Act 1999 (Cth), Section 303CD.

${ }^{130}$ Ramin is listed in Appendix II of the Convention on International Trade in Endangered Species of Wild Fauna and Flora (Washington, DC, 3 March 1973; in force 1 July 1975) ('CITES'); see A. Schloenhardt, n. 26 above, at 14.

${ }^{131}$ Environmental Protection Biodiversity Conservation Act, n. 129 above, Section 303BB.

${ }^{132}$ CITES, n. 130 above, Appendix II.

${ }^{133}$ However, merbau is being considered for listing by Indonesia. See A. Schloenhardt, n. 26 above, at 14.
} 
the difficulty. ${ }^{134}$ Civil processes that form part of the AML toolkit may work more successfully.

\section{CONFISCATION OF PROCEEDS}

Confiscation under the Commonwealth Proceeds of Crime Act allows for forfeiture of criminal assets based on conviction or for forfeiture based on a civil procedure. If based on a conviction, the original crime must have been an indictable offence or a 'serious offence'. ${ }^{135}$ Following conviction, the Commonwealth Director of Public Prosecutions can apply for forfeiture of the property comprising the proceeds. ${ }^{136}$ In the case of a serious offence, a pecuniary penalty may also be imposed. ${ }^{137}$

To initiate a 'civil forfeiture', ${ }^{138}$ the Director of Public Prosecutions must demonstrate, on the balance of probability, that the money or property is the proceeds of an indictable offence that occurred within six years prior to the launch of confiscation proceedings. Once the presumption is raised, a defendant bears the burden of rebutting by proving that, on the balance of probability, the relevant property was not the proceeds of such an offence. ${ }^{139}$ Forfeited property vests in the government, ${ }^{140}$ but proceeds that are forfeited from transnational offences can be shared with a concerned foreign country. ${ }^{141}$ Civil forfeiture under the Proceeds of Crime Act for a foreign indictable offence related to illegal logging, such as theft, corruption, participation in a transnational organized crime group, or tax or tariff evasion, can therefore proceed without even a conviction in Indonesia. ${ }^{142}$ For civil proceedings, the evidence need only prove, on the balance of probability, that the merbau flooring timber was produced from logs taken by such means in Indonesia less than six years before the Australian confiscation proceedings commenced.

Under the Illegal Logging Prohibition Act 2012, forfeiture orders can be made by a court against any property in association with a criminal conviction, and civil forfeiture

${ }^{134}$ D. Brack 'Limitations of Money Laundering Techiques: Controlling Imports of Illegally Logged Timber', G. Rose, n. 19 above, 173. For a successful AML prosecution for a foreign environmental crime, see: United States v. Bengis, 631 F.3d 33, 35 (2d Cir. 2011); discussed in M. Asner, 'To Catch a Wildlife Thief: Strategies and Suggestions for the Fight against Illegal Wildlife Trafficking', 12:2 University of Pennsylvania Asian Law Review (2017), 1.

${ }^{135}$ A 'serious offence' is one that is subject to a penalty of imprisonment for three years or more; or involves narcotics, money laundering, terrorism, people smuggling, embezzling AU\$10,000 or more; or certain offences against the Financial Transaction Reports Act 1988 (Cth) concerning transactions of AU\$50,000 or more; see: Proceeds of Crime Act 2002 (Cth), Section 338.

${ }^{136}$ Other Australian jurisdictions, i.e. all States and Territories, have their own conviction based forfeiture legislation: Criminal Assets Recovery Act 1990 (NSW); Crime (Confiscation of Profits) Act 1993 (Tas); Criminal Property Confiscation Act 2000 (WA); Criminal Proceeds Confiscation Act 2002 (Qld); Criminal Property Forfeiture Act 2002 (NT); Confiscation of Criminal Proceeds Act 2003 (ACT); Criminal Assets Confiscation Act 2005 (SA).

${ }^{137}$ Proceeds of Crime Act 2002 (Cth), Section 121.

${ }^{138}$ Ibid., Section 47. Australian states and territories have civil forfeiture provisions in their forfeiture legislation, other than Tasmania.

${ }^{139}$ Ibid., Section 54. The court is not precluded from making a forfeiture order when there is doubt regarding the actual commission of the offence; ibid., at Section 47.3.

${ }_{140}$ Ibid., Part 2.2. Additional complexities can include third-party claims to the property.

141 Ibid., Section 298(c).

${ }^{142}$ Ibid., especially Section 49.1(c)(ii). 
of prohibited imports is also available without a court order. ${ }^{143}$ Therefore, failure to exercise due diligence in importing P.T. Graha Buana Indonesian timber products can result in confiscation and forfeiture of Hardware Wholesaler property. This is simpler than AML forfeiture because it operates locally and does not require a predicate foreign offence, dual criminality or a prior conviction and there is less need for mutual legal assistance.

\section{CONCLUSION}

Indonesian law enforcement efforts against timber barons for illegal logging have been ineffective in local prosecutions. It is clear that much of the illegal logging is transnational organized crime. Although no single solution is likely for this complicated problem, international cooperation could promote better law enforcement for Indonesian forests. Strategies such as building Indonesian capacity to manage forest resources and enforce existing regulations could be supplemented by responsible foreign controls on imported timber. Australia, the European Union and the United states have introduced due diligence requirements on importers to identify and certify timbers as sustainably and legally sourced. These are obligatory and supported by unilateral criminal prohibitions that operate in the importation jurisdiction. It is important that these positive developments in import controls be introduced also in China - destination for half the world's illegally logged timber, and in other major wood processing markets such as Vietnam.

Timber legality regimes are not infallible, however, and even diligent importers may be duped by corrupt licensing, forgery and other fraudulent practices along the line of production and delivery of timber. Thus, AML law enforcement remains a tool to complement timber legality frameworks. The transnational reach of AML laws affords an opportunity to tackle the principal beneficiaries of illegal logging. Nevertheless, the legal complexities of dual criminality in predicate offences and uncertainties of mutual legal assistance can frustrate AML criminal proceedings. Therefore, AML civil procedures for confiscating the presumed proceeds of crime, with a reduced burden of proof, are a simpler and more effective alternative to criminal processes.

The legal tools to combat illegal logging discussed in this Indonesia-Australia case study could be applied across other forms of transnational environmental crime. An era of improved international coordination of national AML laws and of international cooperation in law enforcement to combat a broader range of transnational environmental crimes is possible.

Gregory Rose is a Professor with the School of Law at the University of Wollongong and a long-standing member of its Australian National Centre for Ocean Resources and Security (ANCORS). His research expertise is in international law, particularly national security and marine environmental protection. In the area of environmental protection, his journal and chapter publications focus on transnational environmental crime and mechanisms for the effective implementation of international environmen-

\footnotetext{
${ }^{143}$ Illegal Logging Prohibition Act, n. 48 above, Section 10.
} 
tal standards. His two most recent books are Detention in International Military Operations: The Future Law (Martinus Nijhoff, 2016) (co-edited with B. Oswald) and Following the Proceeds of Environmental Crime, Forests Fish and Filthy Lucre (Routledge, 2014). He is currently writing a book on illegal fishing as transnational crime.

The author gratefully acknowledges James Welch for his contribution to the original draft of this article. 